INVITED 2007 CARROLL

D. Clark Lecturer

AT THE

UNIVERSITY OF KANSAS 



\title{
DeCIPHERING THE Global: Its Spaces, Scales And Subjects
}

\author{
SASKIA SASSEN \\ Columbia University \\ PREPARED BY \\ ADA VAN ROEKEL-HUGHES
}

Bob Antonio: I was just going to hold up Saskia's book, but I see that there are a number of them over there. Second news, it's an honor to introduce Saskia Sassen. She's just returned to Columbia Sociology Department and their committee on Global Studies. She's a centennial professor, a visiting professor, at London School of Economics [LSE]. And has just left a chair at the University of Chicago. Saskia has an enormous corpus of work. This is just a small sample of what she's done. Her Mobility of Labor and Capital, published in 1988, and The Global City, 1991, are kind of classic books. And I think that Saskia really is one of the founding voices of this whole big interdisciplinary course - arguably the biggest — on globalization. She was in it early along with her colleague at the LSE, David Harvey, and has made an enormous contribution to it. Her work is critical, has focused on political economy, but also covers gender, very sensitive to space and time, averts the simplistic use of globalization as being placeless and stateless and there's a major contribution here. Her new book, Territory, Authority, Rights, the most recent one, is really a major book. It's received glowing reviews so far. I suggest even going on Amazon.com and even looking at them. I got one from my buddy, Alessandro Bonanno, who I think you know, who's going to be using it in Brazil this fall and gave me a glowing review of it today. In any regard, we're lucky to have here someone who really has been a major voice in this unusually important discourse, also a public intellectual in the best sense of the term, and one who has been very good and very generous with her students. This is what I 
hear, enormously active chairing students. She has this book, that's just came out. Another one, the Sociology of Globalization, which is about to come [Saskia "It's out actually"] . . . [laughter]

Saskia Sassen: It's a great pleasure to be here. What Bob did not mention is that we were classmates at the University of Notre Dame. Do you remember that? I had my dissertation rejected, because the economists and the sociologists on my committee let lose on the occasion of the oral defense. This was partly because I was a contrarian and had decided that I wanted to combine economics and sociology - two disciplines that at that time, at that university, did not like each other, and partly because I was shy I let them run rough over me at the defense. In the end, they mailed me my $\mathrm{PhD}$. I never went back. The first time I went back was to give the Hesburgh Lectures in Ethics and Politics (of all possible subjects!), in honor of the former president of Notre Dame. And there he was, sitting in the first row. I was very tempted to start by saying "this is the university where I tried to get my $\mathrm{PhD}$ ". But it was somehow not the right thing to say. But there were more ironic twists to come. You know, Bob, this is like having a little private conversation in public: this year the University of Notre Dame for the first time instituted an award for the most distinguished alumnus of to graduate with a $\mathrm{PhD}$ across all disciplines and divisions, including the sciences. I was honored with that prize. And there I stood again, in front of the President and the Deans, and I was so tempted to mention that my doctoral committee had initially rejected my dissertation. After that rejection I went to France to study philosophy. . . . I don't mean that this is a model - get your dissertation rejected and when you get old, get all the prizes you ever wanted. No, it doesn't work that way always.

Now then, onto the Clark Lecture, which I am delighted and honored to give.

This is a time of epochal, even if partial, transformations. ${ }^{1}$ Some use the notion of globalization to capture the change - a "national versus global contest" view. Others focus on the War on Terror

\footnotetext{
${ }^{1}$ This is based on a larger project published as Territory, Authority, Rights: From Medieval to Global Assemblages (Princeton University Press 2008). All references in this essay are to this source; readers can also find full bibliographic elaboration of the issues raised here.
} 
and its aftermath, emphasizing the "state of exception" that gives governments legal authority to abuse its powers. There are several other interpretations and namings of the character of today's major transformation. But this suffices to make the point that much of the commentary on the major changes of our time pivots on the notion that the national state is under attack, or at the minimum, that it is suffering the erosion of its territorial protections.

But the major change is not fully captured in these types of understandings. A key yet much overlooked feature of the current period is the multiplication of a broad range of partial, often highly specialized, global assemblages of bits of territory, authority and rights once firmly ensconced in national institutional frames. ${ }^{2}$ These assemblages cut across the binary of national versus global. They inhabit national institutional and territorial settings, and they span the globe in what are largely trans-local geographies connecting multiple subnational spaces.

These assemblages include at one end private, often very narrow, frameworks such as the lex constructionis - a private "law" developed by the major engineering companies in the world to establish a common mode of dealing with the strengthening of environmental standards in a growing number of countries, in most of which these firms are building. At the other end of the range they include far more complex (and experimental) entities, such as the first ever global public court, the International Criminal Court, which is not part of the established supranational system and has universal jurisdiction among signatory countries. Beyond the fact of the diversity of these assemblages, there is the increasingly weighty fact of their numbers - over 125 according to the best recent count. The proliferation of these systems does not represent the end of national states, but it does begin to disassemble bits and pieces of the national.

If you see through the eye of the national state, these assemblages look like inchoate geographies. But they are actually the bits of a new reality in the making.

${ }^{2}$ This is clearly an analysis that emerges from European history, with all the limitations that entails. Critical here is Gayatri Spivak's thinking about the diverse positions that can structure an "author's" stance. 


\section{Bits of a New Reality}

Using this lens to look at some current, often minor and barely visible, developments opens up some interesting vistas. For instance, Hizbollah in Lebanon can be seen as having shaped a very specific assemblage of territory, authority, and rights, that cannot be easily reduced to any of the familiar containers - nation-state, internal minority-controlled region, such as the Kurdish region in Iraq, or a separatist area such as the Basque region in Spain. Similarly, the emerging roles of major gangs in cities such as Sao Paulo contribute to produce and/or strengthen types of territorial fractures that the project of building a nation-state sought to eliminate or dilute. Besides their local criminal activities, they now often run segments of global drug and arms dealing networks; and, importantly, they are also increasingly taking over "government" functions: "policing," providing social services and welfare assistance, jobs, and a new elements of rights and authority in the areas they control.

We also see these novel mixes of territory, authority and rights in far less visible or noticed settings. For instance, when Mexico's (former) President Fox met with undocumented Mexican immigrants during his visit to the US this past May, his actions amounted to the making of a new informal jurisdiction. His actions did not fit into existing legal forms that give sovereign states specific types of extraterritorial authority. Nonetheless, his actions were not seen as particularly objectionable; indeed, they were hardly noticed. Yet these were, after all, unauthorized immigrants subject to deportation if detected, in a country that is now spending almost 2 billion dollars a year to secure border control.. But no INS or other police came to arrest the undocumented thus exposed, and the media barely reacted, even though it was taking place at a time when Congress was debating whether to criminalize illegal immigrants. Or When Chavez, seen as an "enemy" of sorts by the US government, is somehow enabled (through the state-owned oil enterprise) to bring oil to the poor in a few major cities in the US. All of these are minor acts, but they were not somehow acceptable or customary even a short time ago. They can be seen as producing novel types of mostly informal jurisdictions. 
Emphasizing this multiplication of partial assemblages contrasts with much of the globalization literature. It has tended to assume the binary of state vs. national state, and to focus on the powerful global institutions that have played a critical role in implementing the global corporate economy and gotten states to implement the associated policies. My focus here, opens up the analysis to a far broader range of components, including powerless actors, in what we describe as globalization, and it repositions the powerful global regulators, such as the (reinvented) IMF or the WTO as bridging events for an epochal transformation, rather than as the transformation itself. The actual dynamics getting shaped are far deeper and more radical than such entities as the WTO or the IMF, no matter how powerful they are as foot soldiers. These institutions should rather be conceived of as powerful capabilities for the making of a new order - they are instruments, not the new order itself. Similarly, I argue (2006: ch 4) that the Bretton Woods system was a powerful capability that facilitated some of the new global formations that emerge in the 1980s but was not itself the beginning of the new order as is often asserted.

I see in this proliferation of partial assemblages a tendency toward a disaggregating and, in some cases, global redeployment, of constitutive rules once solidly lodged in the nation-state project, one with strong unitary tendencies (2006: chs 4, 5 and 6). Since these novel assemblages are partial and often highly specialized, they tend to be centered in particular utilities and purposes (chap 5, 8 and 9). The normative character of this landscape is, in my reading, multivalent - it ranges from some very good utilities and purposes to some very bad ones, depending on one's normative stance (?). Their emergence and proliferation bring several significant consequences even though this is a partial, not an all-encompassing development. They are potentially profoundly unsettling of what are still the prevalent institutional arrangements (nation-states and the supranational system) for governing questions of war and peace, for establishing what are and what are not legitimate claims, for enforcing the rule of law. A different matter is whether these established arrangements are effective at it, and whether justice is secured. The point here is that their decomposition would partly 
undo established ways of handling complex national and international matters. The emergent landscape I am describing promotes a multiplication of diverse spatio-temporal framings and diverse normative (mini)orders where once the dominant logic was toward producing (grand)unitary national spatial, temporal, and normative framings (chaps 8 and 9).

This proliferation of specialized orders extends even inside the state apparatus. I argue that we can no longer speak of "the" state, and hence of "the" national state versus "the" global order. There is a novel type of segmentation inside the state apparatus, with a growing and increasingly privatized executive branch of government aligned with specific global actors, notwithstanding nationalist speeches, and a hollowing out of the legislature whose effectiveness is at risk of becoming confined to fewer and more domestic matters (2006: ch 4). A weak and domesticated legislature weakens the political capacity of citizens to demand accountability from an increasingly powerful and private executive, since the legislature gives citizens stronger standing in these matters than the executive. Further, the privatizing of the executive partly has brought with it an eroding of the privacy rights of citizens - a historic shift of the private-public division at the heart of the liberal state, even if always an imperfect division. ${ }^{3}$

A second critical divergence is between the increasing alignment of the executive with global logics and the confinement of the legislature to domestic matters. ${ }^{4}$ This results from three major trends. One is the growing importance of particular components of the administration, such as ministries of finance and central banks (respectively Treasury and Federal Reserve in the US), for the implementing of a global corporate economy; these components actually gain power because of globalization. Secondly, the global

\footnotetext{
${ }^{3}$ This is a complicated issue that I do not address here, but see (2006: ch 6). One question is whether there is a necessary relationship between an increasingly privatized executive branch and the erosion of citizens privacy rights.

${ }^{4} \mathrm{An}$ issue here is the relationship between this executive branch alignment with global logics, on the one hand, and, on the other, the proliferation of various nationalisms. I address this in 2006, ch. 6 and ch 9. Helpful here is Calhoun's (1998) proposition that nationalism is a process articulated with modernity; this makes room for the coexistence of globalization and nationalization.
} 
regulators (IMF, WTO, and others) only deal with the executive branch; they do not deal with the legislature. This can strengthen the adoption of global logics by the executive. A third becomes evident in such cases as the Bush-Cheney Administration's support for the Dubai Ports attempted acquisition of several major port operations in the US. In contrast to these trends, the legislature has long been a domestic part of the state, something which begins to weaken its effectiveness as globalization expands over the last two decades. This then also weakens the political capacity of citizens in an increasingly globalized world.

\section{Avoiding Master Categories}

A major methodological, theoretical and political implication of the type of analysis I am proposing is that it is insufficient to focus on the nation-state and the global system as two distinct entities. The transformations afoot criss-cross this binary, and enter the national and even the state apparatus itself.

To historicize both the national and the global as constructed conditions, I have taken three transhistorical components present in almost all societies and examined how they became assembled into different historical formations. (This is fully developed in the larger project on which this paper is based (2006)). These three components are territory, authority, and rights (TAR). Each can assume specific contents, shapes, and interdependencies across diverse historical formations. The choice of these three rests partly on their foundational character and partly on the contingency of my fields of knowledge. One could, and I hope someone will, choose additional components or replace one or another of these.

Territory, authority, and rights are complex institutionalizations arising from specific processes, struggles, and competing interests. They are not simply attributes. They are interdependent, even as they maintain their specificity. Each can, thus, be identified. Specificity is partly conditioned by levels of formalization and institutionalization. Across time and space, territory, authority, and rights have been assembled into distinct formations within which they have had variable levels of performance. Further, the types of 
instruments and capabilities through which each gets constituted vary, as do the sites where each is in turn embedded - private or public, law or custom, metropolitan or colonial, national or supranational, and so on.

Using these three foundational components as analytic pathways into the two distinct formations that concern me in the larger project - the national and the global — helps avoid the endogeneity trap that so affects the globalization literature. Scholars have generally looked at these two complex formations in toto, and compared them to establish their differences. This is not where I start. Rather than comparing what are posited as two wholes - the national and the global-I disaggregate each into these three foundational components (territory, authority, and rights). They are my starting point. I dislodge them from their particular historically constructed encasements - in this case, the national and the global - and examine their constitution and institutional location in these different historical formations, and their possible shifting across institutional domains. I develop some of this empirically in the next section, but a quick example would be the shift of what were once components of public authority into a growing array of forms of private authority. One thesis that arises out of this type of analysis is that particular national capabilities are dislodged from their national institutional encasement and become consitutive of, rather than being destroyed or sidelined by globalization. ${ }^{5}$

This type of approach produces an analytics that can be used by others to examine different countries today in the context of globalization or different types of assemblages across time and space. $^{6}$

\footnotetext{
${ }^{5}$ In the larger project (2006: chs 1, 8 and 9) there are lengthy discussions of questions of method and interpretation. I propose a distinction between capabilities (for example, the rule of law) and the organizing logics (the national, the global) within which they are located. Thus capabilities are multivalent: they can switch organizing logics, with the latter shaping their valence.

${ }^{6}$ I use the concept assemblage in its most descriptive sense. However, several scholars have developed theoretical constructs around this term. Most significant for the purposes of this book is the work of Deleuze and Guattari (Deleuze \& Guattari (1987 p.504-5).D and G: A Thousand Plateaux: Capitalism and Schizofrenia. Minneapolis: University of Minessota press. 1987:504-5 , for whom "assemblage" is a contingent ensemble of practices and things that can be differentiated (that is,
} 
In the modern state, TAR evolve into what we now can recognize as a centripetal scaling where one scale, the national, aggregates most of what there is to be had in terms of TAR. Though never absolutely, each of the three components is constituted overhwelmingly as a national domain and, further, exclusively so. Where in the past most territories were subject to multiple systems of rule, the national sovereign gains exclusive authority over a given territory and at the same time this territory is constructed as coterminous with that authority, in principle ensuring a similar dynamic in other nation-states. This in turn gives the sovereign the possibility of functioning as the exclusive grantor of rights. Territory is perhaps the most critical capability for the formation of the nation-state, while today we see ascend a variety of assemblages for which it is not; thus for the global regulators authority is more critical than territory.

Globalization can be seen as destabilizing this particular scalar assemblage. What scholars have noticed is the fact that the nation-state has lost some of its exclusive territorial authority to new global institutions. What they have failed to examine in depth is the specific, often specialized rearrangements inside the highly formalized and institutionalized national state apparatus aimed at instituting the authority of global institutions. This shift that is not simply a question of policymaking - it is about making a novel type of institutional space inside the state. In overlooking such rearrangements it is also easy to overlook the extent to which critical components of the global are structured inside the national producing what I refer to as a partial, and often highly specialized, denationalizing of what historically was constructed as national.

they are not collections of similar practices and things) and that can be aligned along the axes of territoriality and deterritorialization. More specifically, they posit that particular mixes of technical and administrative practices "extract and give intelligibility to new spaces by decoding and encoding milieux" (1987:504-5). There are many more elaborations around the concept assemblage, including not surprisingly, among architects and urbanists (vide the journal Assemblages). While I find many of these elaborations extremely important and illuminating, and while some of the assemblages I identify may evince some of these features, my usage is profoundly untheoretical compared to that of the above-cited authors. I simply want the dictionary term. I locate my theorization elsewhere, not on this term. 
Thus today particular elements of TAR are becoming reassembled into novel global configurations. Therewith, their mutual interactions and interdependencies are altered as are their institutional encasements. These shifts take place both within the nation-state, for example, shifts from public to private, and through shifts to the inter- and supra-national and global levels. What was bundled up and experienced as a unitary condition (the national assemblage of TAR) now increasingly reveals itself to be a set of distinct elements, with variable capacities for becoming denationalized. For instance, we might say that particular components of authority and of rights are evincing a greater capacity to partial denationalization than territory; geographic boundaries have changed far less (except in cases such as the disintegration of the Soviet Union) than authority (i.e., the greater power of global regulators over national economies) and rights (the further institutionalizing of the international human rights regime). It points to possibly sharp divergence between the organizing logics of the earlier international and current global phases; these are often seen as analogous to the current global phase, but I argue this understanding may be based on a confusion of analytical levels. In earlier periods, including Bretton Woods, that imperial logic was geared toward building national states, typically through imperial geographies; in today's phase, it is geared toward setting up global systems inside national states and national economies, and in that sense, at least partly denationalizing what had historically been constructed as national. This denationalizing can take multiple concrete forms: to mention two critical ones, global cities and specific policies and institutions within the state itself.

\section{Specialized Assemblages as New Types of Territoriality}

Next I develop some of these issues empirically by focusing on emergent articulations of territory, authority, and rights that unsettle what has been the dominant articulation, that characterizing the modern state. I will use the concept of territoriality, usually used to designate the particular articulation of TAR in the modern state. Here I denaturalize the term and use it to capture a far broader range of such articulations. But the national state is the standard 
against which I identify these following four types of territoriality assembled out of "national" and "global" elements, with each individual or aggregate instance evincing distinct spatio-temporal features. These four types of instances unsettle national state territoriality - the territory of the national is a critical dimension in play in all four. (There are other emergent assemblages I examine in the larger project, 2006).

A first type of territoriality can be found in the development of new jurisdictional geographies. Among the more formalized instances are a variety of national legal actions which notwithstanding their transnational geographies can today be launched from national courts. The critical articulation is between the national (as in national court, national law) and a global geography, outside the terms of traditional international law or treaty law. A good example are the lawsuits launched by the Washington-based Center for Constitutional Rights in a national court against nine multinational corporations, both American and foreign, for abuses of workers' rights in their offshore industrial operations, using as the national legal instrument the Alien Torts Claims Act. In other words, this is a global three-sited jurisdiction, with several locations in at least two of those sites - the locations of the headquarters (both the US and other countries), the locations of the offshore factories (several countries), and the court in Washington. Even if these lawsuits do not quite achieve their full goal, they signal it is possible to use the national judiciary for suing US and foreign firms for questionable practices in their operations outside their home countries. Thus, besides the much noted new courts and instruments (e.g. the new International Criminal Court, the European Court of Human Rights), what this example shows is that components of the national rule of law that once served to build the strength of the national state, are today contributing to the formation of transnational jurisdictions. Another instance is the U.S. practice of "exporting" prisoners to third countries (rendition), de facto to facilitate their torture. This is yet another instance of a territoriality that is both national and non-national. Finally, diverse jurisdictional geographies can also be used to manipulate temporal dimensions. Reinserting a conflict in the national legal system may ensure a slower progression than 
in the private jurisdiction of international commercial arbitration (Sassen 2006: ch 5).

A second type of specialized assemblage that is contributing to a novel type of territoriality is the work of national states across the globe to construct a standardized global space for the operations of firms and markets. What this means is that components of legal frameworks for rights and guarantees, and more generally the rule of law, largely developed in the process of national state formation, can now strengthen non-national organizing logics. As these components become part of new types of transnational systems they alter the valence of (rather than destroy, as is often argued) older national state capabilities. Where the rule of law once built the strength of the national state and national corporations, key components of that rule of law are now contributing to the partial, often highly specialized, denationalizing of particular national state orders. For instance, corporate actors operating globally have pushed hard for the development of new types of formal instruments, notably intellectual property rights and standardized accounting principles. But they need not only the support, but also the actual work of each individual state where they operate to develop and implement such instruments in the specific context of each country. In their aggregate this and other emergent orderings contribute to produce an operational space that is partly embedded in particular components of national legal systems which have been subjected to specialized denationalizations (chapters 4 and 5); thereby these orderings become capabilities of an organizing logic that is not quite part of the national state even as that logic installs itself in that state. Further, in so doing, they often go against the interests of national capital. This is a very different way of representing economic globalization than the common notion of the withdrawal of the state at the hands of the global system. Indeed, to a large extent it is the executive branch of government that is getting aligned with global corporate capital and ensuring this work gets done.

A third type of specialized assemblage can be detected in the formation of a global network of financial centers. We can conceive of financial centers that are part of global financial markets as constituting a distinct kind of territoriality, simultaneously pulled 
in by the larger electronic networks and functioning as localized micro-infrastructures for those networks. These financial centers inhabit national territories, but they cannot be seen as simply national in the historical sense of the term, nor can they be reduced to the administrative unit encompassing the actual terrain (e.g. a city), one that is part of a nation-state. In their aggregate they house significant components of the global, partly electronic market for capital. As localities they are denationalized in specific and partial ways. In this sense they can be seen as constituting the elements of a novel type of multi-sited territoriality, one that diverges sharply from the territoriality of the historic nation-state.

A fourth type of assemblage can be found in the global networks of local activists and, more generally, in the concrete and often place-specific social infrastructure of global civil society. Global civil society is enabled by global digital networks and the associated imaginaries. But this does not preclude that localized actors, organizations, and causes are key building blocks of global civil society as it is shaping up today. The localized involvements of activists are critical no matter how universal and planetary the aims of the various struggles - in their aggregate these localized involvements are constitutive. Global electronic networks actually push the possibility of this local-global dynamic further. Elsewhere I have examined (2006: chapter 7) the possibility for even resource-poor and immobile individuals or organizations to become part of a type of horizontal globality centered on diverse localities. When supplied with the key capabilities of the new technologies - decentralized access, interconnectivity, and simultaneity of transactions - localized, immobilized individuals and organizations can be part of a global public space, one that is partly a subjective condition, but only partly because it is rooted in the concrete struggles of localities.

In principle we can posit that those who are immobile might be more likely to experience their globality through this (abstract) space than individuals and organizations that have the resources and the options to travel across the globe. Sometimes these globalities can assume complex forms, as is the case with first-nation people demanding direct representation in international fora, 
bypassing national state authority - a longstanding cause that has been significantly enabled by global electronic networking. Other times they are more elementary, as is the case with various Forest Watch activists in rain forests around the world. We can see here at work a particular type of interaction between placeless digital networks and deeply localized actors/users. One common pattern is the formation of triangular cross-border jurisdictions for political action which once would have been confined to the national. Local activists often use global campaigns and international organizations to secure rights and guarantees from their national states; they now have the option to incorporate a non-national or global site in their national struggles. These instances point to the emergence of a particular type of territoriality in the context of the imbrications of digital and nondigital conditions. This territoriality partly inhabits specific subnational spaces and partly gets constituted as a variety of somewhat specialized or partial global publics.

While the third and fourth types of territoriality might seem similar, they are actually not. The subnational spaces of these localized actors have not been denationalized as have the financial centers discussed earlier. The global publics that get constituted are barely institutionalized and mostly informal, unlike the global capital market, which is a highly institutionalized space both through national and international law, and through private governance systems. In their informality, however, these global publics can be seen as spaces for empowerment of the resource-poor or of not very powerful actors. In this sense the subjectivities that are emerging through these global publics constitute capabilities for new organizing logics.

Although these four types of emergent assemblages that function as territorialities are diverse, they all share certain features. First, they are not exclusively national or global but are assemblages of elements of each. Second, in this assembling they bring together what are often different spatio-temporal orders, that is, different velocities and different scopes. Third, this can produce an eventful engagement, including contestations and what we might think of as a "frontier zone" effect - a space that makes possible kinds of engagements for which there are no clear rules. The resolu- 
tion of these encounters can become the occasion for playing out conflicts that cannot easily be played out in other spaces. Fourth, novel types of actors, initially often informal political or economic actors, can emerge in the processes through which these assemblages are constituted. These novel actors tend to be able to access cross-border domains once exclusive to older established actors, notably national states. Finally, in the juxtaposition of the different temporal orders that come together in these novel territorialities, an existing capability can get redeployed to a domain with a different organizing logic. These emergent assemblages begin to unbundle the traditional territoriality of the national, historically constructed overwhelmingly as a national unitary spatio-temporal domain.

\section{Conclusion}

Both self-evidently global and denationalizing dynamics destabilize existing meanings and systems. This raises questions about the future of crucial frameworks through which modern societies, economies, and polities (under the rule of law) have operated: the social contract of liberal states, social democracy as we have come to understand it, modern citizenship, and the formal mechanisms that render certain claims legitimate and others illegitimate in liberal democracies. The future of these and other familiar frameworks is rendered dubious by the unbundling, even if very partial, of the basic organizational and normative architectures through which we have operated, especially over the last century. These architectures have held together complex interdependencies between rights and obligations, power and the law, wealth and poverty, allegiance and exit.

The multiplication of partial, specialized, and applied normative orders produces distinct normative challenges in the context of a still prevalent world of nation-states. Just to mention one instance, I would induce from these trends that normative orders such as religions reassume greater importance where they had until recently been confined to distinct specialized spheres by the secular normative orders of states. I would posit that this is not, as is commonly argued, a fallback on older cultures. On the contrary, 
it is a systemic outcome of cutting-edge developments - not premodern but a new type of modernity that is a kind of default sphere arising out of the partial unbundling of what had been dominant and centripetal normative orders into multiple particularized segmentations. The ascendance of religion is but one outcome, albeit a highly visible one that arouses deep passions. But there are others, and their numbers are growing even as they are rarely as visible as religion.

\section{Biography}

Saskia Sassen is now the Robert S. Lynd Professor of Sociology and Member, Committee on Global Thought at Columbia University after a decade at the University of Chicago and London School of Economics. Her recent books are Territory, Authority, Rights: From Medieval to Global Assemblages (Princeton University Press 2006) and A Sociology of Globalization. (Norton 2007). Other recent books are the $3^{\text {rd }}$, fully updated Cities in a World Economy (Sage 2006), the edited Deciphering the Global (Routledge 2007), and the co-edited Digital Formations: New Architectures for Global Order (Princeton University Press 2005). The Global City came out in a new fully updated edition in 2001. She has now completed for UNESCO a five-year project on sustainable human settlement for which she set up a network of researchers and activists in over 30 countries; it is published as one of the volumes of the Encyclopedia of Life Support Systems (EOLSS) (Oxford, UK: EOLSS Publishers) [http://www.eolss.net]. All together her books are translated into nineteen languages. She has written for The Guardian, The New York Times, Le Monde Diplomatique, the International Herald Tribune, Newsweek International, the Financial Times, and OpenDemocracy.net among others. 


\title{
INTERVIEW WITH SASKIA SASSEN
}

\author{
Prepared By \\ Anna Kern and Gabriella Smith
}

STAR: You were introduced yesterday as an eminent public intellectual. Could you discuss what the title of public intellectual means to you and how your personal politics inform that?

Sassen: There are two ways of being in the public for an academic. One is that you put on a generalist's hat and you basically spout a bit of nonsense. As an academic you have a very hard time coming down to a level that you think is necessary, to make it into brain food so that a person can just swallow and doesn't even have to chew. I really object to that. I always believed that the audience is up to much more, even a non-academic audience. For me, being a public intellectual is entering the political. I have a voice. I have authority. My university has gravitas in the public domain. If I come out in support of a cause or against a move, I should explain it in terms of research findings that I or someone else has gathered, or provide an alternative interpretations that is the result of careful work. I think that is the best I can do. It is not putting on a generalist's hat and spouting nonsense, or superficial tropes.

I recently wrote an editorial in the Guardian of London in support of three sociologists from Germany. They were German citizens - they were not Muslim naturalized citizens - who had been thrown into solitary confinement. They had been there for two weeks, and nobody knew. For what? For writing about gentrification and displacement, stuff that supposedly could lead to terrorist activities. In the German case, the prosecutor had very few choices as to what law to use for an indictment - either a very light violation of the law kind of charge, or a draconian law that came out of the terrorism of the Badder-Meinhoff armed attacks 
decades ago. So the prosecutor wound up using this extreme law. We wrote a very forceful statement that included this argument, about the lack of choices, and the costs for democracy, etc. It made the rounds around the globe. It was picked up by all the major media in Germany, and became a shameful incident: the prosecutor was told by the government to let them go, albeit conditionally. That is a public intellectual's way of clarifying matters. I write regularly for OpenDemocracy a critical web-based publication-I recommend it! — about stuff that is happening out there about which I do research. I bring my opinion and my knowledge about these subjects to clarify, eliminate distortions in the public understanding, but I also bring the complexity of my analysis to bear on such subjects. I don't need to say stuff everybody else is already saying, because that is often what academics wind up doing. My notion of entering the public domain is, in the last analysis, about the political in a very broad sense. There is a whole parallel world where a growing number of academics are involved in constructing alternative explanations of major public issues - this is political work also ... public/political are connected words.

STAR: That leads into another question. You mentioned your latest book, Territory, Authority, Rights: From Medieval to Global Assemblages, has a section on the making of the political. Would you care to expand on that a bit?

Sassen: I think that when you look at history in periods of transformation - periods which unsettle existing arrangements, existing conceptions, existing rethoricizations - one must ask, "What is the account that explains this? " The aim is to produce a persuasive account that is not empty. There are a whole bunch of accounts floating around. The neo-liberal account is probably the best known, "the market knows best". When unsettlements happen the flaws of existing arrangements become legible, their faults become legible, their shortcomings become legible, and a void is often created where even the powerless can enter the picture and begin to reshuffle those very meanings. I think that this is one of those times. So my question then is "Where can we make the political?" In the book I discuss two or three sites. One is the executive branch of govern- 
ment in the current period. The executive branch of government, starting with Reagan, has remade a good part of formal politics by grabbing an enormous amount of power to itself. In the book I have one section that I've titled "The Executive's Privatizing of Its Own Power." So, the executive ceases to be as accountable as it ought. Mind you, I see this as going beyond party politics. It also happened with Clinton - Clinton was just a more sympatique cowboy. My argument is that it's a systemic trend, but political parties and individuals do matter, because under Clinton it was certainly different than under Reagan and Bush/Cheney. Yet the power of the executive was also growing under Clinton. The second argument I make, which comes out of this trajectory is that a good part of the power grab of the executive is not simply the result of the state of exception (in our case the Patriot Act as a national emergency) and hence anomalous; it is the normal condition in the current phase of the liberal state. Sometimes it means well, as with Chavez in Venezuela, sometimes it is close to evil, as with Bush/Cheney.

Another site that I am interested in is how the powerless might make the political. For this I enter the realm of the city, especially global cities: the complex city enables the making of informal politics, politics that does not run through formal systems. It brings politics down so it is not dependent on mediating institutions, formal systems, electoral systems, propaganda machines. Actors who are actually making the political may not necessarily be aware that they are doing so. When immigrants went on the street last year (2006) and claimed the right to have rights, they were making the political. Out of that, by the way, came the first western hemisphere meeting of immigrants, held in Zacatecas (Mexico) in August 2007. Immigrants came from throughout Latin America. In other words, the Bolivians who had migrated to Buenos Ares, the Koreans who had migrated form Peru to Sao Paulo, and of course lots of Mexicans from the US. One of the people who organized this for the US side was from Chicago, a hairdresser. She was not a professor who was going to help. On the agenda of that meeting at Zacatecas was, "What is our politics? What do we want? As immigrants, what are our claims? What do we want to ask from the government?" It is about the right to have rights. Citizenship 
is today still the best vehicle to get rights, to be a rights-bearing subject. But citizenship here is a vehicle: it is not the nationalist project of being an American, an Italian, or whatever. There is today a movement for the rights to the city which makes politics very concrete. There's a global network of mayors now who have signed on to this movement for the rights to the city for everyone, not only the advantaged. When you ask for rights to the city, you're asking for green parks, better public transport, clean air, etc. That makes politics concrete, also often informalizes politics. It makes it immediate rather than mediated. To me these are instances of the making of the political.

On a more abstract level the ascendance of the human rights regime is remaking the political. The International Criminal Court (ICC) is remaking the political. So is the making of new global jurisdictional geographies that I talked about yesterday --that we as citizens don't have to wait for a global state, we can do informal but also formal global politics from national bases. But it's a matter of making them, not simply consuming existing formats, as is voting in elections (which we should of course also do). About this making of jurisdictions, it needs to be distinguished from choosing a jurisdiction: in a dispute that goes to court, people often try to find the right judge, the right jurisdiction to handle it. It's not like that, it's not "forum shopping" - that's the standard phrase. "Let's do it in Alaska because we'll get a better deal," or "Let's do it in Delaware." Corporations always want their disputes settled in Delaware because it's corporate central. The citizens-initiated cases I referred to yesterday were ones that use existing national laws to make new kinds of jurisdictions. To me those are all tools for making the political. Whether and how it eventually is institutionalized and formalized, history will tell. Some of it, I think will remain informal, and informal politics is not a bad thing.

STAR: We talk often about what the term "globalization" refers to. I was wondering if you would like to talk about the "why" of globalization; why globalization now? why are these things we are talking about occurring at this period of history? 
Sassen: Well, something has changed. There is a global corporate economy that didn't exist in this way before. We have always had multinationals. In the late 1800 s the Americans, the Germans, the French, the Brits, they all had multinational corporations. They all had affiliates in each other's countries or in their current or past imperial spaces. The fact of multinationals is not enough to mark, to distinguish the current period. The difference is the level of institutionalization, and the spread. Now a growing number of firms are simply, in one way or the other, involved globally, either directly or indirectly via subcontracts or subsidiaries. I always ask my students "How many multinationals do you think there are today?" They rarely guess the right number. It's well over 200,000. So the difference with the past is made up of two things. One is the actual components: institutional, legal, regulatory, the variety of actors, etc, of the global corporate economy itself. It is simply another order of magnitude; it's a qualitatively different arrangement. The second point is there is a great difference between those past phases and now because in between the national state became such a dominant actor. It succeeded in nationalizing all critical components of the social order: identity, territory, security, law, authority. So the current globalization had to deal with the wall of the national. Past phases were part of (often quite institutionalized) imperial geographies.

So I think what raises the stakes and makes the whole thing more visible and more dramatic is the global corporate economy's expansion, its' growing formalizations, all of this in a context of the institutional thickening of the national, and the rise of the national state as an enormous power, as an actor dominating the international zone. Because the move had been to have all transactions go through the national state, the regulatory state became stronger. So suddenly what you have is an insertion of other actors - corporate economic actors, NGOs, and all types of religious organizations - who are entering domains once exclusive to the national state. This is the critical point. These actors are entering the international space once exclusive to the national state. In the past you had multinational corporations, but they had to run through the state, have authorization. There were tariffs. There were export restrictions. For me the 
big elephant in the global room is the national state. And that is what created the drama. Before, there was a lot of internationalism, but it all ran through highly regulated national systems, the hegemons, and all had to pass through state notions of regulation.

STAR: In the lecture yesterday you discussed how states themselves are doing the work of de-nationalizing - of creating the global within the nation - with regard to finance, trade; and, within the nation-state, the implementation of global jurisdictional geographies, expansive citizenship and the diasporic. At the same time nations and national states still seem to wrestle with the issues surrounding globalization and national sovereignty. How do you rectify this?

Sassen: In prior periods of imperialism there was much reshuffling of the zones of control and of their boundaries. Today, most borders haven't changed. There are a few disputed borders, for instance between Peru and Chile, but these are acts of nationalism. There is of course the decomposition of the Soviet Union into the Commonwealth of Independent States, as they call it. National territories are still overwhelmingly under the exclusive authority of their national state. The borders are still there. However, the change isn't happening at that level, the visible level. It is the series of institutional changes that really captures how the border is changing, even if the actual geography of the territory does not change. The notion that national states have the right to exclusive authority remains a key but the reality is beginning to change. So the question then is, "Where does the difference lie for the current global phase?"

Coming back to your question, the state is still national. Thus sovereignty, nationalism, border control and protection vis-à-vis certain types of flows - all of these become extremely acute precisely because so much else is shifting. I argue, for instance, that we are seeing a renationalizing of membership politics which is an acute reaction to an acute unsettlement of the existing experience of membership. Under the Keynesian regime of the post-WWII decades citizens had far more entitlements. One of the arguments I develop in my new book is that we as citizens are losing rights. Last year we lost five rights. But they were very technical rights so nobody picks up on their loss not even the media. As members of a polity 
our struggle should be to strengthen the rights - bearing subject, whether native or foreign born. It should not be immigrants versus citizens because we're on a slippery slope of losing rights. Nor is it just a matter of jumping onto transnationalism and the aspirational politics involved in transnationalisms and post- nationalisms. I think the question of the national state need not be seen as finished, as many have suggested, but as repositioned, rearticulated, with new content, and a possible denationalizing of membership that can happen deep inside the national.

We are seeing these transformations inside the national and inside the state itself. One of the pieces I did for OpenDemocracy. net, argues that when you look carefully you can see that no matter the nationalist speech acts of the sovereign - the "sovereign" is the designation of the state in international law, in this case Bush/Cheney - the executive branch of the government in liberal democracies is increasing aligned, not alienated, with global logics. This holds whether that is Sarcozy in France, or Blair until recently in the UK, or our government.

One source of executive power is that the major global regulators, notably the IMF and WTO, as well as many lesser known ones, only negotiate with the executive branch. As the global corporate economy and the supranational system have and continue to expand, executive power grows as well and so does the disadvantage of Congress. The executive branch is increasingly aligned with a number of global actors and processes that are critical to the global corporate economy. While the other branches of government are beginning to develop novel international relations (Speaker Pelosi's visit to Syria; the Supreme Court's emergent consideration of foreign law in its deliberations), these do not necessarily feed their power within the state. The development of an institutional apparatus geared towards the global war on terror, with its growing cross-border collaborations, involves largely the executive branch and particular agencies of the public administration. The globalizing of criminal networks for the trafficking of drugs, arms, and people, also feeds into the development of intergovernmental collaborations largely centered in the executive branch. To some extent this is inevitable. The concern here is with detecting the extent to which globalizing 
dynamics feed executive power rather than simply weakening "the" state.

Inter-governmental networks centered largely in the executive have grown well beyond concerns with global security and criminality. The participation by the state in the implementation of a global economic system has engendered a whole range of new types of cross-border collaborations among specialized government agencies focused on the globalization of capital markets, international standards of all sorts, and the new trade order.

Look at Bush. Bush has no problem with economic globalizing logics. The legislature is far more domestic, less international — not such a good thing in a global world.

STAR: In thinking about Global Cities and what these spaces signify in the concept of globalization, what do you think about spaces on the opposite end of the spectrum, what they signify? Places and spaces like Western Kansas, where you find ghost barns signify — in terms of globalization - rural to urban migration, industrialization and globalization of agriculture, migration of agricultural labor. Is there more there to be tapped into?

Sassen: You know, it's funny. I got invited a few years ago to be the keynote speaker for the International Society of Sparsely Populated Areas, which is not my forte. I was very amused and said, "are you sure you want me?" They said "yes" because of precisely the same question you are asking me, "How does your lens triage, interpret, these sorts of sparsely populated spaces?" I think there are multiple issues. Number one, in the case of farm country, say, rather than ghost towns, the geography might be the same as many decades ago - farm lands, cattle grazing lands, etc. - the actual space economy that has developed there now is radically different from the past. It is a corporate space economy; and, in that sense, a new social form. Secondly, one of the issues for me is "What are the global circuits on which these spaces are located?" in this case spaces that look very isolated and where the workforce may be lowly educated, lowly paid? Take forests: forests are located on multiple, highly specialized global circuits. Thirdly, some of the global circuits involve increasingly specialized servicing. When 
you see those corporate farms and that corporate space economy, (today's farmland in much of the US), you are looking at a vast increase in the complexity and level of specialization, as opposed to the family farm where families live, work with the local bank, etc. It may have been an export sector all along, but it was different. So, that geography that we see as rural is actually part of a very specialized global service economy. I make the same case for big harbours - such as Singapore, Hong Kong, Los Angeles, Rotterdam - they are specialized service economies, and not just about cargo. To me it is very important to recover the fact that it's not just about the rurality of the landscape when you leave the cities and are in corporate farmland. Similarly, the vast amounts of cargo in harbours does not exclude the fact that harbors are also a highly specialized service economy-even though the space economy of the services is a different area, it leaves the harbour and enters the city, so to speak.

A final point I would make concerns Germany and its vast industrial heartland, the Ruhr, which belonged to an older industrial phase. It is today a space economy with a lot of small highly specialized firms, a lot of small cities, not mega cities, but also what are now described as "shrinking cities." These are cities that people have left, abandoned as the big factories and mines closed. They are now piles of cement in a slightly devastated rural space. Kansas' ghost barns are another such space, one that coexists with a corporate farm economy. One of the issues for me theoretically is that geographic terrain can be inhabited by several very different space economies. For instance, I argue that a lot of what people see as suburbanization is an older social geography that is still very present. But increasingly that suburban geographic terrain is also inhabited by a space economy that has little to do with the suburban. For instance, Goldman Sachs has an automated trading floor in the suburbs of Connecticut. You might think this is suburban, but no, that space is digitally connected to Wall Street! That is not at all a suburban space economy! It is a Wall Street global financial space economy.

I don't know the landscape you are alluding to, but it just strikes me that it might be a case of a given geographical terrain inhabited by 
more than one space economy. The older space economy is gone, is dead. In some of the shrinking cities in Germany, for instance, there are new inhabitants that are making a new type of space: artists who have little money but want big spaces, immigrants who inhabit those spaces. It has nothing to do with the older, social and economic space and its actors. A final example: the United States also has a rurality, a rural world that is really Third World. There are particular areas in Appalachia, for instance. These are yet other rural spaces.

There are a bunch of issues that one can bring to bear on all of this. We need to interrogate the meaning of "the rural" because the rural is no longer "the rural as different from suburban and the urban." The whole notion of rurality is, in some cases, a changed concept . . . it may be in a rural space but that does not make it a rural social order. It may well be a global corporate order.

STAR: So we need to recode how we think of urban/suburban/rural, much like we need to recode our understanding of powerlessness, as you were saying yesterday?

Sassen: Yes, I think we need to do that. Nor is this the first time recoding has happened. When industrialization hit Europe, the first phase was just manufacturing with hands and tools, not really machine-production. In fact that earlier manufacturing was located also in rural areas; it changed the meaning of the rural economy. Today that is even stronger: it is the rural guided by the logics of urban corporate economies. The rural has lost some of the autonomy it once had as a space. The modes of producing in rural space (think industrial chicken and turkey raising, and corporate agriculture) are actually a massive disruption with the cycles of nature. You know, several multinationals farmed and raised cattle in vast stretches of land in Central America, Kenya, and so on. Over-exploitation of the land, not respecting the cycles and the reproductive conditions of nature has killed the earth in many of these areas. They will recover, but it will take time. I say that this is dead land, and I ask should we keep that land on the global circuits that led to its death? And I say, "Yes, as it captures the trajectory of that un-natural cycle of use." There is a lot of interesting theoretical and analytical work we can do now with the rural. 
STAR: I was wondering if you wouldn't mind giving a few of your impressions on the visit of Iranian President Ahmadinejad to Columbia University and the surrounding controversy, as someone well versed in the various intersections involved.

Sassen: First, when [Ahmadinejad's visit] was announced, it was very controversial. There was a lot of opposition from various groups, donors, etc. So, when the decision was made [to invite Ahmadinejad], Bollinger promised that some tough questions would be asked. I think what happened was that Bollinger did not have the right compass. You can't blame him. We academics, we don't necessarily have the talent to run departments or to be diplomats, or administrators. So, in my view, (and I am not the only one, this is a public debate and conversation), he just did the wrong thing by being so offensive. There was no need to make a martyr out of Ahmadinejad! Nobody needed that! That gave him the high ground right from the beginning.

Now, Ahmadinejad is also in this kind context his own worst enemy, the way he responded, to the question about homosexuality in Iran - "We don't have that! Show me! Show me one!" But with Bollinger, I am sure that some of his pro-Israel supporters encouraged him to do this. I don't know that, but one senses that. He must have checked with people. He is a president of a university which is a corporation. In the past he has demonstrated that he listens to what certain constituencies say. We assume that he thought there was support for this line of attack - to immediately come out with the big guns. I don't know whether he actually checked the content of his comments with his various constituencies. It is one thing to come out with the big guns to say "Mr. President, it is in the spirit. .." I liked the norm that was invoked, but Bollinger undermined the norm. The norm was freedom of speech. The norm was not to create spectacle, but Bollinger managed to make it into spectacle. He did the opposite of freedom of speech. We who all take it seriously, we triage the details that came out. My version was, "the norm, the umbrella was freedom of speech." So, we have to make sure that that norm is enacted at all times. Because of what Bollinger said, it was no longer freedom of speech. It was something else. 
As an academic, when you enter the public domain, you have to be very clear about what norm you operate under. As academics, we are meant to bring something different. We are not politicians, nor diplomats, nor journalists. We do not need to repeat what the media are saying, though we can bring in data to support or contest the media's assertions about a given topic. I am interviewed a lot, and sometimes I simply decline because I can tell they want me to say something that supports whatever position they need supported. They need some talking head to say "that's the way this is." For instance, the Danish cartoons of the prophet Mohammed. That was also a freedom of speech issue. The West, the French, everybody, was saying "freedom of speech." And I said, "You know, when you have just declared a War on Terror and your objective is to hit some sub-group of the Muslim world, then the law, or the freedom of speech norm, ceases to be just a legal condition." I literally said "it becomes a sociological condition." We simply cannot look at this through the lens of freedom of information. It's messier than that! I loved it that many people picked up later that the law is not always just the law. In certain settings the law is also a sociological condition. I think all of this, especially in periods of unsettlement, calls for sociological analysis. It identifies and dismembers a bundle of assumptions. It's important if you enter the political domain as a social scientist to be clear from what stance you are speaking. 